Методами диференційно-термічного, термогравіметричного та диференційно-термогравіметричного аналізів досліджено композити на основі сумішей поліпропілену з поліамідом, котрий попереднъо модифікований монтморилонітом, інтеркальованим полівінілпіролідоном. Показано, що суміші поліпропілену з модифікованим монтморилоніт-полівінілпіролідоновою сумішшю поліамідом відзначаються підвищеною термостійкістю. Встановлено, що за вмісту модифікованого поліаміду в сумішах з поліпропіленом в межах 30 \% мас. зразки композиту характеризуються найвищою термостійкістю

Ключові слова: поліпропілен, поліамід, монтморилоніт, полівінілпіролідон, суміш, нанокомпозит, модифікація, рекристалізація

$\square$

Методами дифференциально-термического, термогравиметрического и дифференциально-термогравиметрического анализов исследованы композиты на основе смесей полипропилена с полиамидом, который предварительно модифицирован монтмориллонитом, интеркалированным поливинилпирролидоном. Показано, ито смеси полипропилена с модифицированным монтмориллонит-поливинилпиролидоновой смесью полиамидом отличаются повышенной термостойкостью. Установлено, ито при содержании модифицированного полиамида в смесях с полипропиленом в пределах $30 \%$ масс. образиы композита характеризуются найвысшой термостойкостью

Ключевые слова: полипропилен, полиамид, монтмориллонит, поливинилпирролидон, смесь, нанокомпозит, модификация, рекристаллизация
UDC 678.746 .744

DOI: $10.15587 / 1729-4061.2017 .108465$

\section{THERMOGRAVIMETRIC RESEARCH INTO COMPOSITES BASED ON THE MIXTURES OF POLYPROPYLENE AND MODIFIED POLYAMIDE}

V. Krasinskyi

$\mathrm{PhD}$, Associate Professor* E-mail: vkrasinsky82@gmail.com

V. Kochube i

$\mathrm{PhD}$, Associate Professor**

E-mail: vicvitkoch@gmail.com

Y. K I y $\mathbf{m}$ *

E-mail: klymyuriy77@gmail.com

O. S u ber l y a k

Doctor of Chemical Sciences, Professor, Head of Department* E-mail: suberlak@polynet.Iviv.ua *Department of Chemical Technology and

Plastics Processing $* \star \star *$

**Department of Physical and Colloid Chemistry***

*** Lviv Politechnic National University S. Bandery str., 12, Lviv, Ukraine, 79013

\section{Introduction}

Creation of polymeric nanocomposites based on the polymers of structural designation is a relevant task at present. Of great interest in obtaining the polymeric nanocomposites is montmorillonite, as a nanoscale heterophase. Montmorillonite (MMT) - affordable raw material - is the main component (up to $85 \%$ ) of bentonite [1]. Montmorillonite has a special matrix structure that provides it with unique properties. In particular, in the aqueous environment the primary crystalline elements of montmorillonite are broken down into layers - nanoscale elements of the structure [2, 3].

At the end of 80 s of the twentieth century, researchers from the concern Toyota obtained the first nanocomposite based on polyamide- 6 and organomodified montmorillonite [4]. This composite was distinguished by increased physical- mechanical and thermal properties. The obtained results defined the prospects for such systems and caused an intensive development of research into this field. Today, the market of the layered-silicate polymeric nanocomposites is developing in the most intensive way with a volume about USD 950 million in 2014 [5].

The first attempts at creating composites based on polymers and aluminosilicates were made in 50 s of the last century [6]. However, the introduction of approximately $40-50 \%$ by weight of clays (bentonite, hector, etc.) did not lead to the improvement of properties of the polymeric material, first of all, because of the unsatisfactory dispersing of a silicate filler [7]. Significant progress in the creation of polymeric-silicate nanocomposites with improved physical and mechanical properties in comparison with the starting polymer and traditional dispersely-filled composites was achieved only in the 90s [8].

\section{Literature review and problem statement}

Recently, scientists have paid much attention to the mixtures based on polypropylene (PP) and polyamide (PA), mixing of which makes it possible to reduce negative characteristics of the starting polymers [9, 10]. In particular, nonpolar polypropylene during mixing with the polar highly hydrophilic polyamide significantly reduces water absorption of the material. Consequently, the effect of moisture on the mechanical and thermal properties of composites is reduced. On the other hand, mixing PP with PA allows expanding the temperature interval of material operation at negative temperatures (temperature of PE fragility reduces) [9]. 
However, obtaining a homogeneous mixture of PP with $\mathrm{PA}$ requires the use of compatibilizers, of a complex chemical structure, as a rule, namely low-ionized PP [10]. But, in this case, the probability of chemical cross-linking of macromolecules is increased as a result of the interaction between anhydrous groups with the peptide ones.

At the same time, paper [11] reported the possibility of obtaining a homogeneous mixture of polyamide with polyvinylpyrrolidone (PVP). This mixture is characterized by a high degree of crystallinity and the higher temperature of crystallization. At the same time, mechanical strength of the material after the modification is little changed. The homogeneity of the mixture is due to the physical interaction between polyamide and PVP based on hydrogen bonds. Such interaction reduces the polarity of both polymers, resulting in the manifestation of hydrophobic fragments of the chains. Formation of such material makes it possible to mix it with the hydrophobic polymers, in particular, with polypropylene (PP), without employing compatibilizers with a complex chemical structure.

In order to achieve a substantial improvement in the properties of the polymeric material, a uniform distribution of nanoparticles of silicate must be achieved in the polymeric matrix. The largest changes in the physical-chemical properties can be expected when introducing anisometric nanoscale filler to the polymer matrix [12]. Particles of lamellar aluminosilicates, in particular, of montmorillonite, have a significant anisometry [13].

Recently, researchers have been paying much attention to obtaining nanocomposites based on the thermoplastic polymeric matrices and a mineral high-polar aluminosilicate - montmorillonite [9, 12, 14, 15].

In article [16], the nanocomposites $\mathrm{PP} /$ montmorillonite are obtained by the intercalation of melt using a twin-screw extruder. Using a scanning electron microscope, the authors proved that MMT is dispersed evenly at the nanoscale. The test results of mechanical characteristics of such composites showed that strength at bending of the composites with a low content of MMT ( $2 \%$ by weight) was higher than that of PP.

By using the method of intercalation from melt [17], the nanocomposites PP and layered silicate $\mathrm{Na}^{+}$-montmorillonite ( 3 and $7 \%$ by weight) were obtained with the polar modifier - a low-ionized PP of two types that differ in molecular weight and the content of polar groups. The modifier with low molecular weight and high content of polar groups ( $4 \%$ by weight) contributes to the intercalation of PP, but it binds bad with it and worsens its thermal properties in the nanocomposite. A maximum difference between dynamic module of the nanocomposite with $3 \%$ by weight of clay and the PP module is observed at $80{ }^{\circ} \mathrm{C}$ and is around $65 \%$. It is shown that the compatibility of nonpolar and polar polymers controls the crystal structure and thermal properties of the matrix mixture of polymers and can play a dominant role in the thermal-mechanical behavior of nanocomposites based on the partially crystalline polymers.

In paper [18], the surface of montmorillonite before mixing with PP is modified by a dispersing agent (DAG) with a high molecular weight. It is shown that DAG significantly affects the strength of mechanical properties. Results of the scanning electron microscopy reveal that MMT is dispersed in $\mathrm{PP}$ in the form of particles.

As we can see, in most cases, mixing PP with MMT leads to lower mechanical strength of the composite. Although one may note the growth of strength and thermal characteristics during introduction of $3 \%$ by weight of MMT to PP, which is modified by the low-ionized PP [17].

At the same time, mixing a polar PA with a polar MMT provides increased rigidity and mechanical strength of the composite [19] and substantially increases temperature of the start of destruction [12].

Authors of article [20] demonstrated that the intercalated nanocomposite is formed during modification of polyamide- 6 by nanosilicate.

The nanocomposites PP/PA-6/organomontmorillonite, obtained by the intercalation in melt [10], have higher strength at stretching and bending, compared to the unfilled PP, which is subsequently reduced with increasing content of a nanofiller. Impact viscosity of nanocomposites is higher than the impact strength of unfilled PP and reaches $9.61 \mathrm{~kJ} / \mathrm{m}^{2}$. In the presence of organomontmorillonite, the rate of crystallization of PP and PA-6 increases.

Given this, the authors propose a technique for obtaining a nanocomposite based on the mixture PP/PA-6 with enhanced temperature resistance, using the positive effect of PVP and MMT on obtaining a homogeneous mixture [11] and improving temperature characteristics of the composite [12, 17]. For this purpose, it is proposed at first to obtain a nanocomposite based on PA-6 with MMT, which is intercalated by PVP. Next, to obtain a mixture based on PP and the synthesized nanocomposite. It is assumed that the application of MMT, intercalated by PVP, will contribute to the enhancement of thermostability of PA-6. At the same time, PVP, associated with PA-6, will contribute to an increase in the compatibility of polypropylene with polyamide, which will exclude the use of reactive compatibilizers with a complex chemical structure.

\section{The purpose and objectives of the study}

The purpose of present study was to investigate, applying the methods of thermogravimetric analysis, a correlation between thermal characteristics of the newly created nanocomposites based on the mixture PP/PA- 6 with montmorillonite modified with the help of PVP, and to determine the optimal composition of a nanocomposite with the enhanced temperature resistance and a wide temperature interval of the viscous-fluid state.

To accomplish the goal, the following tasks were set:

- to work out a technique for obtaining nanocomposite based on the mixture PE/PA-6 with montmorillonite modified by using PVP;

- to investigate thermal resistance of nanocomposites based on the mixture PE/PA-6 employing the methods of complex thermogravimetric (TGA), differential-thermogravimetric (DTGA) and differential-thermal analysis (DTA);

- to determine the actual, suitable for practical application, composition of the mixture of polypropylene with modified polyamide.

\section{Materials and methods to study thermal resistance of composites based on the mixtures of polypropylene and modified polyamide}

4. 1. Examined materials and research methods used during experiment

In the present work, we used polypropylene (PP), Moplen HF501N mark (The Netherlands), with $\mathrm{MFI}_{230 / 2.16}=$ 
$=9.50 \mathrm{~g} / 10 \mathrm{~min}$, thermal resistance $155^{\circ} \mathrm{C}$ by Vick, density $\rho^{20}=0.900 \mathrm{~g} / \mathrm{cm}^{3}$, bulk density $\rho_{b}=0.53 \mathrm{~g} / \mathrm{cm}^{3}$.

Polyamide PA6-210/310 (Belarus) with $\mathrm{MFI}_{230 / 2.16}=$ $=19 \mathrm{~g} / 10 \mathrm{~min}$, melting temperature $215^{\circ} \mathrm{C}$, density $\rho^{20}=$ $=1.12 \mathrm{~g} / \mathrm{cm}^{3}$, relative viscosity 2.68. Before using, PA-6 was dried under vacuum at $90{ }^{\circ} \mathrm{C}$ for 2 hours.

As a modifier for polyamide, we used the montmorillonite-polyvinylpyrrolidone mixture (MPM), obtained from the solution in the ultrasound field, with the ratio of components MMT:PVP=1:5 [21, 22].

To obtain the mixture, polyvinylpyrrolidone (PVP) with a molecular weight of $12600 \pm 2700$ was used, softening point $140-160{ }^{\circ} \mathrm{C}$, density $1.19 \mathrm{~g} / \mathrm{cm}^{3}$ at $20{ }^{\circ} \mathrm{C}$, which was dried before mixing under vacuum at $60-70{ }^{\circ} \mathrm{C}$ for $2-3$ hours.

We also used montmorillonite of the mark Fluka from the company SIGMA-ALDRICH with a surface area of $250 \mathrm{~m}^{2} / \mathrm{g}$ and $\mathrm{pH} 4-5$.

Thermal analysis of both the starting components and the compositions based on them was conducted using the derivatograph Q-1500D, connected to an IBM- compatible personal computer. The given device allows simultaneous determining the loss of mass (thermogravimetry - TG), the rate of weight loss (differential thermogravimetry - DTG) and thermal effects (differential-thermal analysis - DTA) for one sample. Research was conducted under dynamic mode in the ambient air. The samples were heated at a rate of $3{ }^{\circ} \mathrm{C} / \mathrm{min}$. A batch was about $200 \mathrm{mg}$ on average. Oxide of aluminum was a reference substance. Derivatographic study of the samples was conducted in a temperature range of $20-600^{\circ} \mathrm{C}$.

The study objects were: sample 1 - pure PP; sample 2 the composition PP:(PA-6/MPM $)=70: 30$ agglomerate; sample 3 - PP:(PA-6/MPM $)=0: 30$ - sample 2 after injection molding; sample $4-$ the composition $\mathrm{PP}:(\mathrm{PA}-6 / \mathrm{MPM})=$ $=30: 70-$ agglomerate; sample $5-\mathrm{PP}:(\mathrm{PA}-6 / \mathrm{MPM})=30: 70-$ sample 4 after injection molding.

$\mathrm{X}$-ray studies were conducted on the diffractometer DRON-4-07. Emitting lamps with a copper anode and an Ni-filter were used. The study was performed in the region of angles $2 \theta$ from 4 to $45 \theta$, the length of measuring step was 0.10 , period of pulse measurement $8 \mathrm{~s}$.

4. 2. Working out a technique for obtaining a nanocomposite based on the mixtures of polypropylene with modified polyamide and fabrication of samples for thermogravimetric studies

In order to improve compatibility of montmorillonite with thermoplastic polymers, we previously obtained a mixture of montmorillonite with polyvinylpyrrolidone in the ratio MMT:PVP=1:5, in the form of finely-dispersed powder in line with the procedure described in [21,22].

It is known that the technique for mixing and the conditions of the implementation of the process exert a significant influence on the properties of the obtained mixtures. In order to obtain composites with a complex of high operational and technological characteristics, based on polypropylene and modified PA-6, the mixing was conducted in several stages.

At the first stage, a mixture was obtained based on polyamide (PA-6) and MPM in the ratio 90:10\% by weight. By mixing MPM in the melt of PA- 6 during 15 min in the plunger-capillary plasticizer (nozzle diameter $\mathrm{d}=2.095 \pm 0.005 \mathrm{~mm}$ ) at a temperature of $230{ }^{\circ} \mathrm{C}$ and a load of $5 \mathrm{~kg}$, we obtained strands, which were ground using a rotary-knife crusher.

At the second stage, the obtained agglomerate was dried under a vacuum at $80{ }^{\circ} \mathrm{C}$ and mixed mechanically with polypropylene in the ratios 30:70 and 70:30\% by weight. Next, in the thermoplastic automatic machine Kuasy 32/25, we performed the plastication of the obtained compositions at the following parameters: temperature by the sections of injection cylinder $170,195,230{ }^{\circ} \mathrm{C}$, mixing time $4-5 \mathrm{~min}$. The rods were obtained by the intrusion method, which were ground using a rotary-knife crusher.

At the third stage, the samples to be studied were obtained from the received compositions by injection molding, in the form of standard blades, in the thermoplastic automatic machine Kuasy 32/25 at the following optimal technological parameters: temperature in the sections of material cylinder of the molding machine $-170,195,235{ }^{\circ} \mathrm{C}$; temperature of the molding shape $-68-70{ }^{\circ} \mathrm{C}$; pressure of molding - $100 \mathrm{MPa}$; holding time under pressure $-6 \mathrm{~s}$; holding time for cooling $-25 \mathrm{~s}$.

\section{Results of thermal analysis of the composites based on the mixtures of polypropylene and modified polyamide}

Thermolysis of samples $2-5$ is conducted at six stages (Table 1, Fig. 1). At stage 1, in the temperature range of $20-147^{\circ} \mathrm{C}$, the separation of physically bound water occurs. This process is accompanied by a slight weight loss of the samples and the emergence of not so deep endothermal effects on the DTA curves. Samples 4, 5 have a much larger moisture content, due to the presence in their composition of a large amount of hygroscopic substances (PVP, MMT, PA-6).

Table 1

Results of thermogravimetric analysis of the composites samples

\begin{tabular}{|c|c|c|c|}
\hline Sample & $\begin{array}{c}\text { Thermolysis } \\
\text { stage }\end{array}$ & $\begin{array}{c}\text { Temperature } \\
\text { range, }{ }^{\circ} \mathrm{C}\end{array}$ & Weight loss, \% \\
\hline \multirow{3}{*}{1} & $\mathrm{I}$ & $140-170$ & - \\
\hline & II & $230-400$ & 65.6 \\
\hline & III & $400-600$ & 34.4 \\
\hline \multirow{6}{*}{2} & $\mathrm{I}$ & $20-126$ & 0.74 \\
\hline & II & $126-164$ & - \\
\hline & III & $164-211$ & - \\
\hline & IV & $211-328$ & 13.86 \\
\hline & $\mathrm{V}$ & $328-414$ & 65.25 \\
\hline & VI & $414-600$ & 18.0 \\
\hline \multirow{6}{*}{3} & $\mathrm{I}$ & $20-140$ & 0.9 \\
\hline & II & $140-160$ & - \\
\hline & III & $160-218$ & 0.6 \\
\hline & IV & $218-322$ & 7.1 \\
\hline & $\mathrm{V}$ & $322-439$ & 77.9 \\
\hline & VI & $439-600$ & 13 \\
\hline \multirow{6}{*}{4} & $\mathrm{I}$ & $20-147$ & 2.62 \\
\hline & II & $147-159$ & - \\
\hline & III & $159-241$ & 3.23 \\
\hline & IV & $241-349$ & 13.43 \\
\hline & $\mathrm{V}$ & $349-471$ & 59.29 \\
\hline & VI & $471-600$ & 8.6 \\
\hline \multirow{6}{*}{5} & $\mathrm{I}$ & $20-138$ & 2.29 \\
\hline & II & $145-163$ & - \\
\hline & III & $163-230$ & 1.26 \\
\hline & IV & $230-328$ & 14.53 \\
\hline & $\mathrm{V}$ & $328-463$ & 73.55 \\
\hline & VI & $463-600$ & 8.52 \\
\hline
\end{tabular}




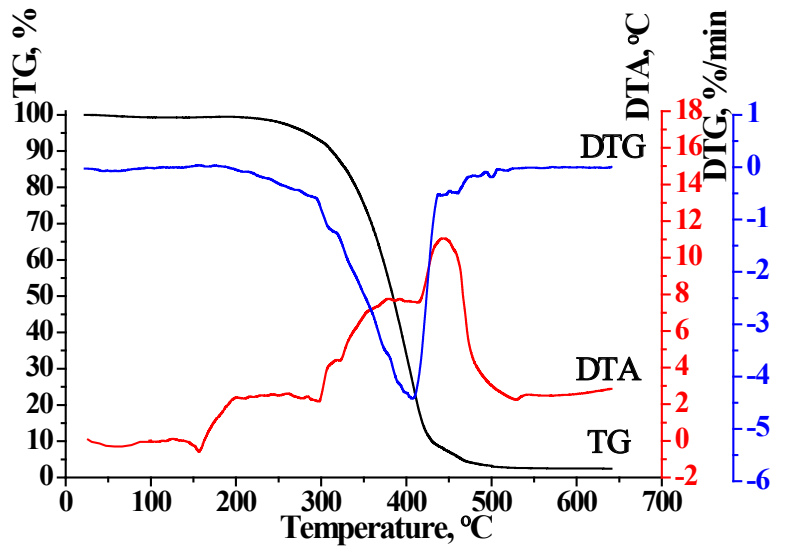

$a$

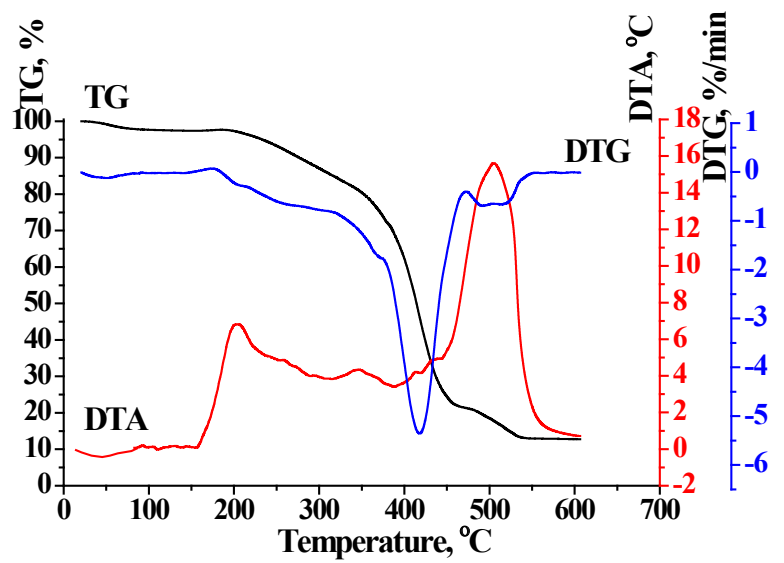

$c$

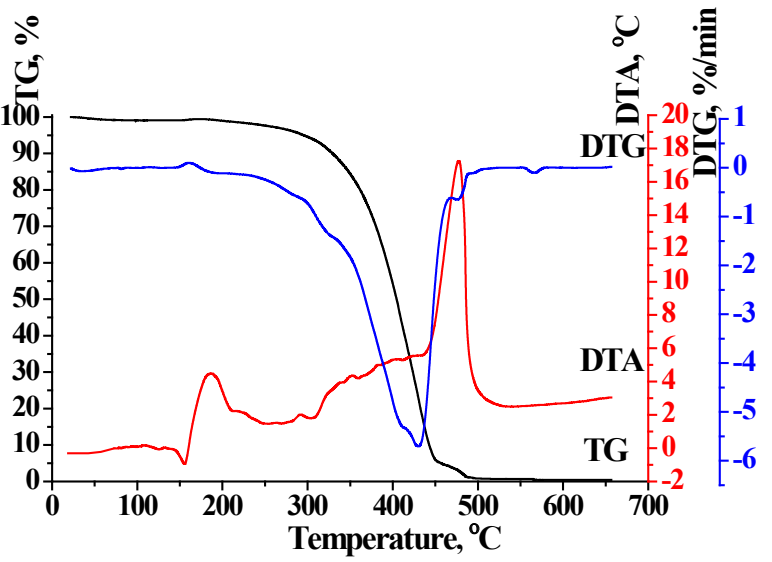

$b$

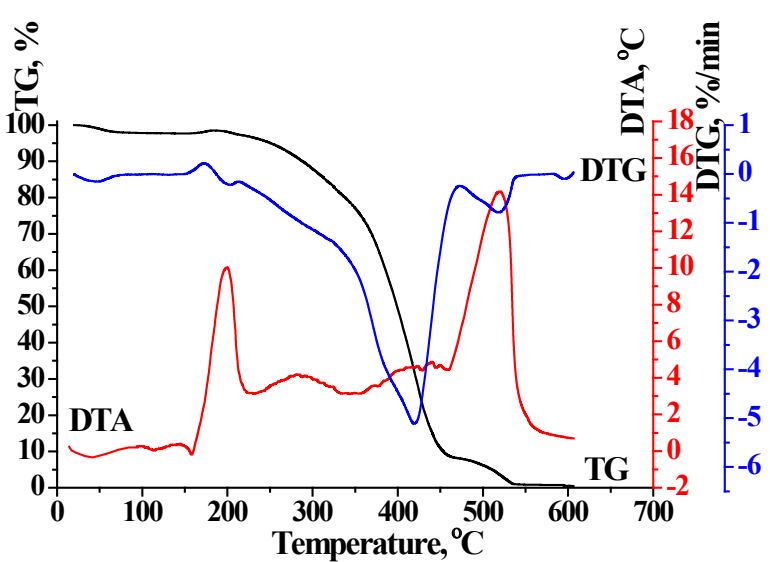

$d$

Fig. 1. Thermograms of composites samples based on polypropylene and polyamide- 6 , previously modified by the mixture montmorillonite- polyvinylpyrrolidone (MPM): $a$ - sample $2-$ the composition

PP:(PA-6/MPM) $=70: 30-$ agglomerate; $b$ - sample $3-\mathrm{PP}:(\mathrm{PA}-6 / \mathrm{MPM})=70: 30-$ sample 2 after injection molding; $c$ - sample 4 - the composition PP:(PA-6/MPM) $=30: 70$ - agglomerate; $d$ - sample 5 - PP:(PA-6/MPM) $=30: 70-$ sample 4 after injection molding

In the temperature range of $126-164^{\circ} \mathrm{C}$, at stage 2 of the thermolysis, the DTA curves of the compositions samples start to demonstrate an endothermic effect without a weight loss, which corresponds to the process of material melting (Fig. 1). This effect is the deepest for samples 2, 3, which are characterized by the higher content of PP, while for sample 4 an extremum of melting endoeffect is not clearly expressed.

At stage 3 of the thermolysis, in the temperature interval of $159-241^{\circ} \mathrm{C}$, the DTA curves of samples $3-5$ exhibit a clearly pronounced exothermic effect occurs (Fig. 1). This effect indicates, first of all, the intensity of the course of recrystallization processes of polyamide, modified by the montmorillonite-polyvinylpyrrolidone mixture. Crystalline phase of the modified PA-6, according to the results of an X-ray analysis, manifests itself at angles $2 \theta=20-30^{\circ}$ (Fig. 2,a). Moreover, for samples 3, 5, which have undergone repeated thermal treatment in the thermoplastic automatic machine, extrema of the effects are more intensive. This is explained by the fact that the rapid cooling of a material in the molding shape does not make it possible to form the natural crystal structure of the modified polyamide (Fig. 2,b). A wide peak of this exoeffect for sample 4 indicates the formation of a supramolecular structure of the low level of organization and the high degree of polydispersity of the supramolecular structure. Additional confirmation of the course of recrystallization processes during thermolysis of the samples that have undergone repeated thermal treatment in the thermoplastic automatic machine are the significant differences in the radiographs of these samples (Fig. 2). In particular, in the radiograph of sample 3 (Fig. $2, b$ ), there are no peaks at all at angles $2 \theta=28.9^{\circ}$, $25.6^{\circ}, 23.7^{\circ}$, and $21.1^{\circ}$, which are characteristic for sample 2 (Fig. 2,a). The reaction of PVP oxidation is also not ruled out in this range of temperatures [23], which is accompanied by a slight weight loss of the samples (Table 1$)$.

In the temperature interval of $211-349{ }^{\circ} \mathrm{C}$ (stage 4 of thermolysis), there occur the processes of hydrolytic and oxide destruction of PVP and PA-6, which are accompanied by weight loss of the samples and the emergence of endothermic effects on the DTA curves. Samples 2, 3, which contain $30 \%$ by weight of modified polyamide, are distinguished by the higher thermal resistance in comparison with the samples containing $70 \%$ by weight of the modifier. Temperature of the onset of thermo-oxidation destruction of sample 3 is the highest and is within a range of $300{ }^{\circ} \mathrm{C}$ (Fig. 1, $b$ ). The samples of compositions containing the higher amount of modified PA-6 have a lower temperature of destruction, which, however, is higher than that of the sample of pure PP has (temperature of thermo-oxidation destruction of PP is $235{ }^{\circ} \mathrm{C}$ ) (Fig. 1, 3). In the process of 
hydrolysis, samples 2, 3 lose weight less intensively (Table 1). Sample 3 has the highest thermal resistance, which loses only $7.1 \%$ by weight in the process of destruction, in contrast to the rest of the samples of compositions whose weight loss at this stage is $13-15 \%$. Loss of weight by samples 2 and of pure PP (sample 1), which in this temperature range undergoes thermo-oxidation destruction processes, are almost identical. Samples 4, 5 are distinguished by the highest weight loss (Table 1). Thus, it is established that by using the mixing of PP with polyamide, which is modified by MPM, it is possible to increase thermal resistance of the composites against thermo-oxidation destruction. Effects of increasing the temperatures of thermo-oxidation destruction of compositions depend on the ratio of components and the method of processing. Such results make it possible to increase considerably the intervals of temperature parameters of the injection molding process under the pressure of the designed composites, which will allow controlling in a wide range the operational properties of products.

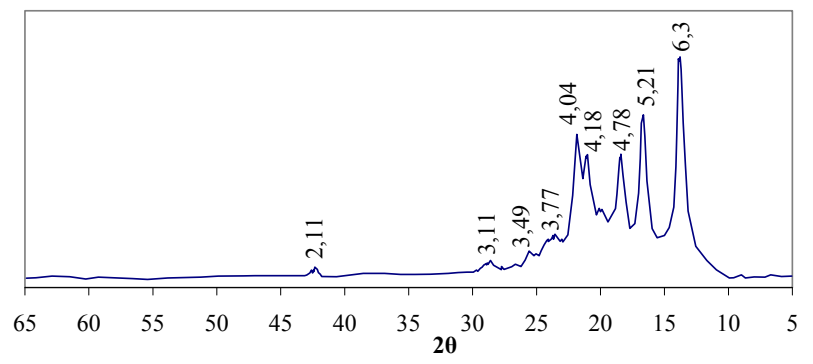

a

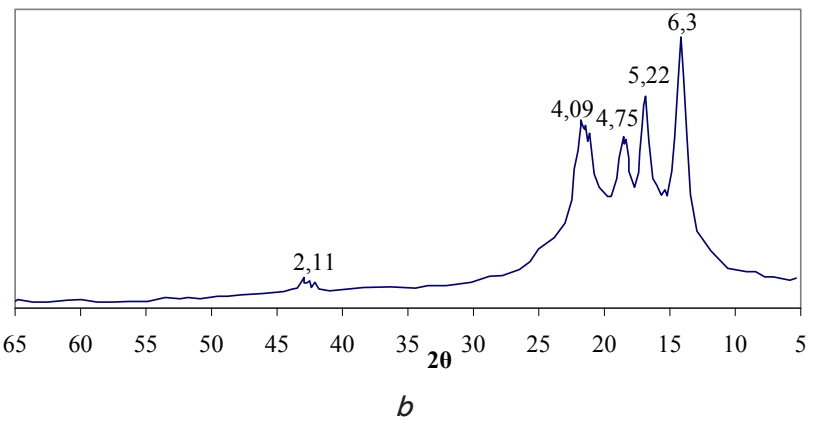

Fig. 2. Radiographs of the composites samples: $a-$ the composition PP:(PA-6/MPM) $=70: 30$ - agglomerate; $b-\mathrm{PP}:(\mathrm{PA}-6 / \mathrm{MPM})=70: 30-$ after injection molding

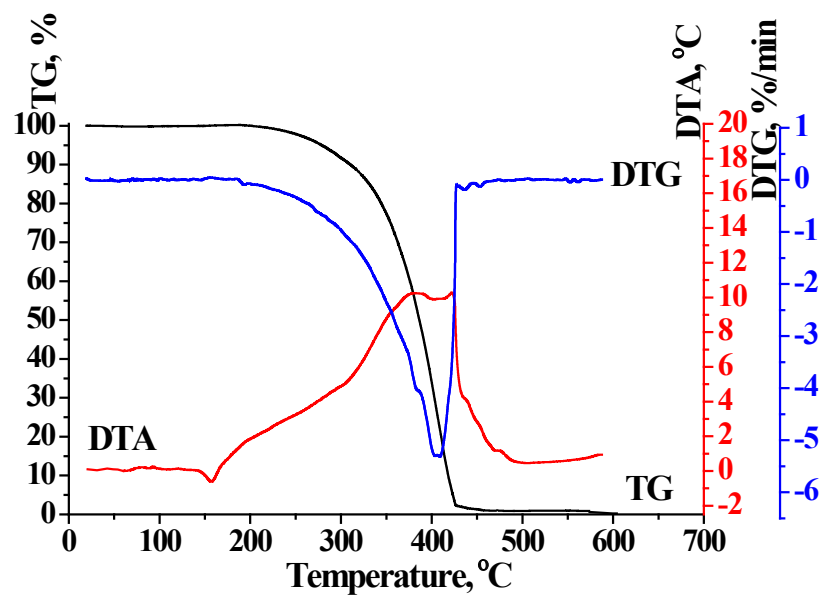

Fig. 3. Differential-thermal analysis of the sample of pure PP
At stage 5 of the thermolysis of samples $2-5$ in the temperature interval $322-471{ }^{\circ} \mathrm{C}$, there occurs a thermo-oxidation destruction of the hydrolysis products, which is accompanied by intensive weight loss and the emergence of exothermic effects on the DTA curves. Samples 3-5 lose weight less intensively in this region, while the exothermic effects are less intense and shifted to the region of higher temperatures compared to PP and sample 2.

At stage 6 of the thermolysis in the temperature interval $414-600{ }^{\circ} \mathrm{C}$, there is a combustion of the carbonated residue with the emergence of a clear exothermic effect on the DTA curves.

Thermolysis of the sample of pure PP takes place over 3 stages (Fig. 3). At stage 1, in the temperature interval $140-70{ }^{\circ} \mathrm{C}$, there is a process of sample melting without a weight loss. The DTA curve exhibits an endothermic effect with a maximum at temperature $157{ }^{\circ} \mathrm{C}$. At stage 2 of the thermolysis in the temperature range $230-400{ }^{\circ} \mathrm{C}$, a thermo-oxidation destruction of the sample occurs with intensive weight loss (Table 1), which finishes by the combustion of the destruction products. The DTA curves displays an exothermic effect with a maximum at temperature $386{ }^{\circ} \mathrm{C}$. At stage 3 of the PP thermolysis, in the temperature range $400-600{ }^{\circ} \mathrm{C}$, a combustion of the carbonized residue takes place, with the emergence of an exothermic effect on the DTA curve with a maximum at $422^{\circ} \mathrm{C}$.

\section{Discussion of results of thermogravimetric studies into the mixtures of polypropylene with modified polyamide}

The regularities of obtaining nanocomposites based on the mixture PE/PA-6 with montmorillonite modified by using PVP were established. In these nanocomposites, PA-6 and MMT contribute to the improvement of thermal resistance of the material, while PVP improves compatibility of the polar PA-6 with a hydrophobic PP.

By analyzing results of the termogravimetric studies, it can be argued that the nanocomposites were obtained on the basis of homogeneous mixtures of PP with the modified PA-6. Homogeneity of the mixtures is confirmed by the presence of one peak on the DTA curves (Fig. 1), which characterizes the process of polymers melting in the region of temperatures $126-164^{\circ} \mathrm{C}$.

The nanocomposites obtained are characterized by the enhanced thermal resistance (temperature of the onset of thermo-oxidation destruction is $300{ }^{\circ} \mathrm{C}$ compared with $235^{\circ} \mathrm{C}$ for the starting PP) and a wide region of the viscous-fluid state. Given this, such materials could be used for manufacturing structural products by traditional methods. The nanocomposites developed based on the mixtures of polypropylene and modified polyamide have wider temperature intervals of the viscous-fluid state $-126-300{ }^{\circ} \mathrm{C}$. This makes it possible, by changing the modes of processing, to influence the structure and properties of products, especially taking into account the difference in crystallization of the material depending on the conditions and the method of processing.

Taking into account an analysis of the scinetific literature and the effects of increasing temperature characteristics with a decrease in the amount of modified polyamide (Table 1, Fig. 1), the composites are promising that contain lower quantity of polyamide, modified by MPM. Therefore, in the future, we plan to undertake research into similar materials with small additions of the modified polyamide. 


\section{Conclusions}

1. We worked out a three-stage technique for obtaining homogeneous nanocomposites based on the mixture PP/ PA-6 with montmorillonite modified by PVP, which rules out the use of complex compatibilizers. In the given nanocomposites, PA-6 and MMT contribute to an increase in the thermal resistance of a material, while PVP improves compatibility of the polar PA-6 with hydrophobic PP.

2. In the course of thermogravimetric studies, it was established that the mixtures of polypropylene with polyamide, modified by the montmorillonite-polyvinylpyrrolidone mixture, are distinguished by rather high thermal resistance. The largest thermal resistance (temperature of destruction is $300{ }^{\circ} \mathrm{C}$ ) is demonstrated by the composi- tion PP:(PA-6/MPM $)=70: 30$, which underwent repeated thermal treatment in the thermoplastic automatic machine during injection molding. Thus, it is established that by using the mixing of PP with polyamide modified by MPM, it is possible to improve thermal resistance of composites against a thermo-oxidation destruction. Effects of increasing temperatures of the thermo-oxidation destruction of composites depend on the ratio of components and the method of processing.

3. Based on the obtained results, it was established that the mixture of polypropylene with modified polyamide in the ratio $70: 30 \%$ by weight, respectively, is the most suitable for application and processing. Composites on the basis of such a mixture are characterized by highest thermal resistance $-300^{\circ} \mathrm{C}$ compared with $235^{\circ} \mathrm{C}$ for the starting PP.

\section{References}

1. En-guang, Z. Effect of a high molecular weight dispersant on the properties of the montmorillonite/polypropylene composite material [Text] / Z. En-guang // Journal of the Daqing Petroleum Institute. - 2009. - Vol. 1. - P. 56-59.

2. Ahmad, M. B. Modification of montmorillonite by new surfactants [Text] / M. B. Ahmad, W. H. Hoidy, N. A. B. Ibrahim, E. A. J. Al-Mulla // J. Eng. Appl. Sci. - 2009. - Vol. 4, Issue 3. - P. 184-188.

3. Kiliaris, P. Polymer/layered silicate (clay) nanocomposites: An overview of flame retardancy [Text] / P. Kiliaris, C. D. Papaspyrides // Progress in Polymer Science. - 2010. - Vol. 35, Issue 7. - P. 902-958. doi: 10.1016/j.progpolymsci.2010.03.001

4. Kovalevski, V. V. Fullerene-like structures in shungite and their physical properties [Text] / V. V. Kovalevski, N. N. Rozhkova, A. Z. Zaidenberg, A. N. Yermolin // Mol. Mat. - 1994. - Vol. 4. - P. 77-80.

5. Mucha, M. Crystallization of isotactic polypropylene containing carbon black as a filler [Text] / M. Mucha, J. Marszalek, A. Fidrych // Polymer. - 2000. - Vol. 41, Issue 11. - P. 4137-4142. doi: 10.1016/s0032-3861(99)00706-5

6. Zymankowska-Kumon, S. Assessment Criteria of Bentonite Binding Properties [Text] / S. Zymankowska-Kumon // Archives of Foundry Engineering. - 2012. - Vol. 12, Issue 3. - P. 139-142.

7. Youssef, A. M. Synthesis and utilization of poly (methylmethacrylate) nanocomposites based on modified montmorillonite [Text] / A. M. Youssef, F. M. Malhat, A. A. Abdel Hakim, I. Dekany // Arabian Journal of Chemistry. - 2017. - Vol. 10, Issue 5. - P. 631-642. doi: 10.1016/j.arabjc.2015.02.017

8. Omurlu, C. Interaction of surface-modified silica nanoparticles with clay minerals [Text] / C. Omurlu, H. Pham, Q. P. Nguyen // Applied Nanoscience. - 2016. - Vol. 6, Issue 8. - P. 1167-1173. doi: 10.1007/s13204-016-0534-y

9. Liang, M. R. Research on Mechanical Properties and Crystallization Performance of PP/PA6/OMMT Composite [Text] / M. R. Liang, W. Y. Jiao, H. Hui, Y. D. Yi // Plastics Science and Technology. - 2010. - Vol. 3. - P. 65-69.

10. Guowang, H. Research Progress of Preparation and Properties of Organic Montmorillonite Filled Polypropylene/PA6 Nanocomposites [Text] / H. Guowang, P. Xiangfang // Plastics Science and Technology. - 2008. - Vol. 11. - P. 94-97.

11. Gnatowski, A. Functional materials based on PA6/PVP blends [Text] / A. Gnatowski, O. Suberlak, P. Postawa // Journal of Achievements in Materials and Manufacturing Engineering. - 2006. - Vol. 18, Issue 1-2. - P. 91-94.

12. Beatrice, C. A. G. Nanocomposites of polyamide 6/residual monomer with organic-modified montmorillonite and their nanofibers produced by electrospinning [Text] / C. A. G. Beatrice, C. R. dos Santos, M. C. Branciforti, R. E. S. Bretas // Materials Research. 2012. - Vol. 15, Issue 4. - P. 611-621. doi: 10.1590/s1516-14392012005000089

13. Suberlyak, O. V. Influence of Aluminosilicate Filler on the Physicomechanical Properties of Polypropylene-Polycaproamide Composites [Text] / O. V. Suberlyak, V. V. Krasins'kyi, V. V. Moravs'kyi, H. Gerlach, T. Jachowicz // Materials Science. - 2014. Vol. 50, Issue 2. - P. 296-302. doi: 10.1007/s11003-014-9721-8

14. Tesarikova, A. Ethylene-Octene Copolymers/Organoclay Nanocomposites: Preparation and Properties [Text] / A. Tesarikova, D. Merinska, J. Kalous, P. Svoboda // Journal of Nanomaterials. - 2016. - Vol. 2016. - P. 1-13. doi: 10.1155/2016/6014064

15. Dulebova, L. The Influence of Modifying HDPE on Properties of the Surface [Text] / L. Dulebova, T. Garbacz, V. Krasinskyi, B. Duleba // Materials Science Forum. - 2015. - Vol. 818. - P. 101-104. doi: 10.4028/www.scientific.net/msf.818.101

16. Chang, D. Effect of Low Frequency Vibration on Property of PP/MMT Blends [Text] / D. Chang, L. Li-hui, X. Jing, S. Kai-zhi // Polymer Materials Science \& Engineering. - 2006. - Vol. 5. - P. 178-181.

17. Ji-Sheng, M. Microstructure and Morphology of PolypropyIene/Clay Nanocomposites Synthesized via Intercalative Polymerization [Text] / M. Ji-Sheng, Z. Shi-Min, Q. Zong-Neng, H. You-Liang, Z. Shu-Fan // Chemical Journal of Chinese Universities. 2002. - Vol. 4. - P. 734-738.

18. Zhou, L. Investigation on Photooxidative Degradation of Polypropylene/Organomontmorillonite Nanocomposites [Text] / L. Zhou, Y. Zhao, M. Yang, D. Wang, D. Xu // Spectroscopy and Spectral Analysis. - 2010. - Vol. 30, Issue 1. - P. 109-113.

19. Huang, J. C. Preparation and properties of montmorillonite/organosoluble polyimide hybrid materials prepared by a one -step approach [Text] / J. C. Huang, Z. K. Zhu, X. D. Ma, X. F. Qian, J. Yin // Journal of Materials Science. - 2001. - Vol. 36. - P. 871-877.

20. Volkova, T. S. Osobennosti vliyaniya nanosilikatov na izmenenie svoystv razlichnyh polimernyh i kleyashchih sistem [Text] / T. S. Volkova, A. Yu. Isaev, A. P. Petrova // Klei. Germetiki. Tekhnologyi. - 2013. - Issue 1. - P. 16-20. 
21. Krasinskyi, V. Operational properties of nanocomposites based on polycaproamide and modified montmorillonite [Text] / V. Krasinskyi, O. Suberlyak, Yu. Klym // Acta Mechanica Slovaca. - 2016. - Vol. 20, Issue 1. - P. 52-55.

22. Krasinskyi, V. V. Termohravimetrychni doslidzhennia polivinilpirolidonu, modyfikovanoho montmorylonitom [Text] / V. V. Krasinskyi, V. V. Kochubei, Yu. V. Klym, I. Haidos // Visnyk NU “Lvivska politekhnika”. - 2015. - Issue 812. - P. 378-382.

23. Suberlyak, O. V. Vliyanie kompleksoobrazovaniya na polimerizatsiyu 2-oksietilenmetakrilata v prisutstvyi polivinilpirrolidona [Text] / O. V. Suberlyak, V. Y. Skorohoda, I. G. Thir // Vysokomolekulyarnye soedineniya. - 1989. - Vol. 31. - P. 336-340.

Представлені кінетичні закономірності металізації механічно активованого цинком порошкоподібного полівінілхлориду в розчинах хімічного відновлення. Досліджено вплив рН середовища та кількості металу активатора на швидкість осадження міді на активованій полімерній поверхні. Встановлено, що зміною рН середовища можна ефективно впливати на процес металізації. Волюметричним методом, за кількістю виділеного водню, показано, що оптимальним $р$ Н розчинів хімічної металізації, для проходження реакиії відновлення міді формальдегідом, є 12. Зростання рН розчинів, а також кількості металу активатора, збільшує кількість відновленої міді в результаті обмінної реакції з цинком

Ключові слова: металополімерні композити, функціональні композити, полівінілхлорид, хімічне відновлення, швидкість реакції, металеві наповнювачі

Представленные кинетические закономерностях металлизации механически активированного иинком порошкообразного поливинилхлорида в растворах химического восстановления. Исследовано влияние рН среды и количества металла активатора на скорость осаждения меди на активированной полимерной поверхности. Установлено, ито изменением рН среды можно эффективно влиять на процесс металлизации. Объемным методом, по количеству выделенного водорода, показано, ито оптимальным рН растворов химической металлизачии, для прохождения реакиии восстановления меди формальдегидом, является 12. Рост рН растворов, а также количества металла активатора, увеличивает количество восстановленной меди в результате обменной реакции с цинком

Ключевые слова: металлополимерные композиты, функииональные композиты, поливинилхлорид, химическое восстановление, скорость реакиии, металлические наполнители

$\square$

口-

\section{Introduction}

Despite their distinctive complex of high technical properties, polymers in some cases demonstrate significant

\section{RESEARCH INTO KINETIC PATTERNS OF CHEMICAL METALLIZATION OF POWDER-LIKE POLYVINYLCHLORIDE}

V. Moravskyi

$\mathrm{PhD}$, Associate Professor* E-mail: vmoravsky@gmail.com

I. Dzi a m an

$\mathrm{PhD}$, Junior Research*

E-mail: iradzyaman@gmail.com

S. Suberliak Engineer*

E-mail: Sophiia.A.Suberliak@|pnu.ua

M. K u z n e t s o va

$\mathrm{PhD}$, Associate Professor**

E-mail: kuznetsovam83@gmail.com

T. T s i mbalis t a

Specialist of the highest category, Chairman of the cyclic Commission of chemical technology and engineering

State higher educational institution

"Kalush Polytechnic College"

B. Khmelnicky str., 2, Kalush, Ukraine, 77301

E-mail: tetyana975@ukr.net

L. Du le bova

$\mathrm{PhD}$, Associate Professor

Department of Automobile Production

Technical University of Kosice

Letniaya str., 9, Kosice, Slovak Republic, 04200

E-mail: ludmila.dulebova@tuke.sk

*Department of Chemical Technology of

Plastics Processing

**Department of Thermal Engineering and

Thermal Power Stations***

*** Lviv Polytechnic National University

S. Bandery str., 12, Lviv, Ukraine, 79013

disadvantages. One of the major shortcomings that limits the scope of application of polymeric materials is the low capacity to conduct electric and thermal energy. It is the high insulating properties of polymers regarded as their 